\title{
Recent advances in understanding and preventing human
}

\section{papillomavirus-related disease [version 1; peer review: 3}

\section{approved]}

\author{
Karin Hellner ${ }^{1}$, Lucy Dorrell ${ }^{2,3}$ \\ ${ }^{1}$ Nuffield Department of Obstetrics and Gynaecology, University of Oxford, Women's Centre, John Radcliffe Hospital, Oxford, UK \\ ${ }^{2}$ Nuffield Department of Medicine, University of Oxford, NDM Research Building, Old Road Campus, Headington, Oxford, UK \\ ${ }^{3}$ Oxford NIHR Biomedical Research Centre, University of Oxford, The Joint Research Office, Block 60, Churchill Hospital, Old Road, \\ Headington, Oxford, UK
}

V1 First published: 14 Mar 2017, 6(F1000 Faculty Rev):269

https://doi.org/10.12688/f1000research.9701.1

Latest published: 14 Mar 2017, 6(F1000 Faculty Rev):269

https://doi.org/10.12688/f1000research.9701.1

\begin{abstract}
High-risk human papillomaviruses (hrHPV) are responsible for anogenital and oropharyngeal cancers, which together account for at least $5 \%$ of cancers worldwide. Industrialised nations have benefitted from highly effective screening for the prevention of cervical cancer in recent decades, yet this vital intervention remains inaccessible to millions of women in low- and middle-income countries (LMICs), who bear the greatest burden of HPV disease. While there is an urgent need to increase investment in basic health infrastructure and rollout of prophylactic vaccination, there are now unprecedented opportunities to exploit recent scientific and technological advances in screening and treatment of pre-invasive hrHPV lesions and to adapt them for delivery at scale in resource-limited settings. In addition, non-surgical approaches to the treatment of cervical intraepithelial neoplasia and other hrHPV lesions are showing encouraging results in clinical trials of therapeutic vaccines and antiviral agents. Finally, the use of next-generation sequencing to characterise the vaginal microbial environment is beginning to shed light on host factors that may influence the natural history of HPV infections. In this article, we focus on recent advances in these areas and discuss their potential for impact on HPV disease.
\end{abstract}

\section{Keywords}

Human papillomavirus, cervical cancer, HPV lesions

\section{Open Peer Review}

Approval Status

1

2

3

version 1

14 Mar 2017

Faculty Reviews are review articles written by the prestigious Members of Faculty Opinions. The articles are commissioned and peer reviewed before publication to ensure that the final, published version is comprehensive and accessible. The reviewers who approved the final version are listed with their names and affiliations.

1. Marc Arbyn, Scientific Institute of Public Health, Brussels, Belgium

2. Yin Ling Woo, University of Malaya, Kuala Lumpur, Malaysia

3. Sarah Fidler, St Mary's NHS Trust and Imperial College, London, UK

Any comments on the article can be found at the end of the article. 
Corresponding author: Lucy Dorrell (lucy.dorrell@ndm.ox.ac.uk)

Competing interests: The authors declare that they have no competing interests.

Grant information: Lucy Dorrell has received financial support from Oxford NIHR Biomedical Research Centre.

Copyright: ๑ 2017 Hellner K and Dorrell L. This is an open access article distributed under the terms of the Creative Commons Attribution License, which permits unrestricted use, distribution, and reproduction in any medium, provided the original work is properly cited.

How to cite this article: Hellner $\mathrm{K}$ and Dorrell L. Recent advances in understanding and preventing human papillomavirus-related disease [version 1; peer review: 3 approved] F1000Research 2017, 6(F1000 Faculty Rev):269 https://doi.org/10.12688/f1000research.9701.1

First published: 14 Mar 2017, 6(F1000 Faculty Rev):269 https://doi.org/10.12688/f1000research.9701.1 


\section{Introduction}

Human papillomavirus (HPV) is the most common viral infection of the reproductive tract. Even though most HPV infections are asymptomatic and clear spontaneously, persistent infections with "high-risk" (oncogenic) mucosal HPV (hrHPV) cause approximately $5 \%$ of all cancers worldwide. These include almost all cases of cervical cancer-with annually over 500,000 newly diagnosed cases and over 260,000 cervical cancer deaths worldwide-as well as a large proportion of other anogenital carcinomas and oropharyngeal tumours in both women and men ${ }^{1}$. The overall burden of HPV-related disease is difficult to estimate, but it is believed that approximately 600,000 annual cases of cervical, anal, penile, vulvar, and vaginal cancers combined are attributable to hrHPV $^{2-4}$ (Table 1).

Cervical cancer is preventable. In the developed world, women who die from cervical cancer either have had little or no screening throughout their lifetime or have not accessed appropriate treatment for abnormal cytology, hence it is not surprising that the majority (around $85 \%$ ) of the global burden occurs in the lessdeveloped regions with little or no access to screening or prophylactic vaccine programmes. ${ }^{5}$. An additional concern is that the HIV epidemic has disproportionately affected the same regions and is an important contributing factor to the prevalence and persistence of HPV infections ${ }^{6}$. Closing the gap between wealthy and low-income countries in prophylactic HPV vaccine rollout is an
Table 1. High-risk HPV-induced cancers.

\begin{tabular}{|l|l|l|}
\hline Site & $\begin{array}{l}\text { Percentage of cancers } \\
\text { associated with } \\
\text { high-risk HPV infection }\end{array}$ & $\begin{array}{l}\text { Number of cancers } \\
\text { attributable to } \\
\text { high-risk HPV }\end{array}$ \\
\hline Cervix & 100 & 529,500 \\
\hline Anus & 84 & 25,536 \\
\hline Vagina & 70 & 10,500 \\
\hline Penis & 47 & 12,361 \\
\hline Vulva & 40 & 12,000 \\
\hline Oropharynx & 19 & 11,685 \\
\hline
\end{tabular}

Table modified from 3

international priority. However, even if this were to be achieved in the near future, hundreds of millions of women who have already been exposed to hrHPV will remain at risk of developing cervical cancer without access to affordable tools for screening and treatment of pre-invasive disease. In this article, we review innovations in testing and treatment for hrHPV infection and intraepithelial neoplasias from molecular, clinical, and operational perspectives alongside new insights into pathogenesis (summarised in Figure 1).

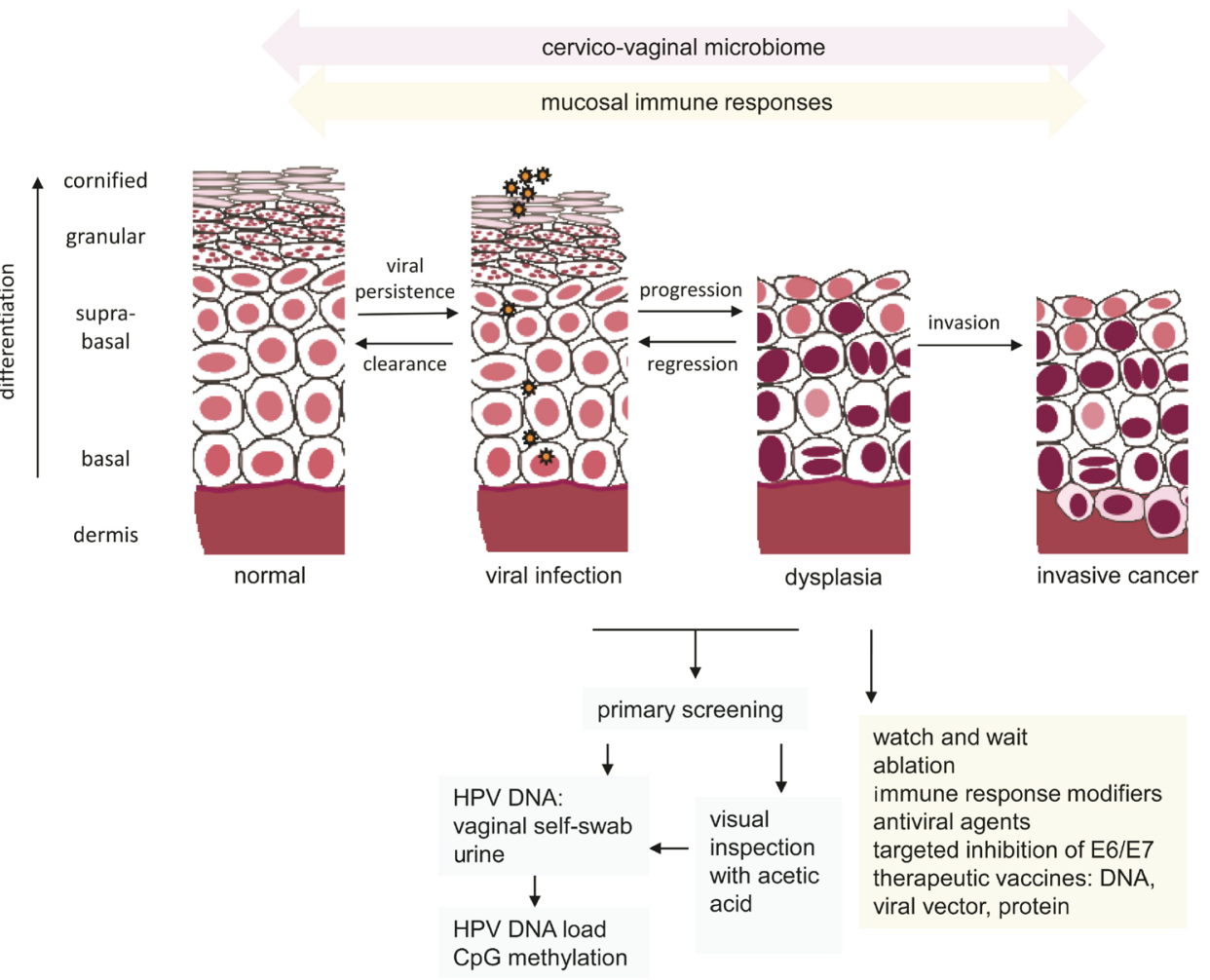

Figure 1. HrHPV-host interactions leading to invasive disease and strategies for intervention. Human papillomaviruses infect cells in the basal layer of squamous epithelia through sites of microtrauma. Infection with high-risk HPV (hrHPV) usually clears spontaneously but persistent infection can lead to intraepithelial neoplasia and rarely, invasive cancer (adapted from 2). Effective innate and adaptive immune responses may lead to regression of dysplastic lesions and clearance of infection. Changes in the cervico-vaginal microbiome have also been implicated in acquisition and clearance of hrHPV infection. Technological advances discussed in this review that have been shown to improve screening and treatment of hrHPV disease are listed. 


\section{Advances in screening}

HPV prevalence varies largely by geographic region, age, gender, and sexual behaviour. HPV-16 antibody prevalence in females aged 9-26 ranged from 0-33\% in Europe and North America to 13-43\% in Africa and Central and South America ${ }^{7}$. HrHPV-16 and -18 DNA prevalence was consistently lower than antibody prevalence; however, rates varied widely according to age. In a study assessing the impact of prophylactic vaccination in England, prevalence of hrHPV DNA (any of 13 types) in women aged 16-24 during

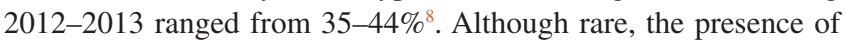
antibodies against hrHPV in prepubertal children may suggest nonsexual (perinatal or horizontal) transmission routes ${ }^{7,9,10}$. HPV-16 and -18 cause nearly $70 \%$ of cervical cancers. HPV-16 also contributes largely to hrHPV-associated vulvar, vaginal, and penile pre-cancer $^{11}$.

For the past five decades, the introduction of screening with the Papanicolaou (Pap) smear test to detect cervical disease early and the implementation of national screening programs have reduced the incidence and mortality of a disease that once caused more deaths amongst women than any other cancer. Liquid-based cytology has widely replaced the conventional Pap testing in recent years, owing to its greater effectiveness, i.e. comparable sensitivity coupled with reduced risk of inadequate sampling ${ }^{12}$. However, in the absence of hrHPV testing, high false-positive detection rates can lead to unnecessary referrals to colposcopy. This triggered the recent use of hrHPV DNA testing to triage women with abnormal cytology at screening. Although this is standard of preventive care in high-income countries, access to screening in LMICs is still limited or unavailable. Population-based models have calculated a projected reduction in cervical cancer incidence of $50-60 \%$ by 2040 if effective screening and/or treatment methods were to be implemented $^{13}$. Fortunately, the growing importance of reducing the burden of HPV-induced cancers has been recently acknowledged by the World Health Organisation and led to the listing of screening and treatment of precancerous lesions to prevent cervical cancer as a "best buy" intervention ${ }^{14}$.

HrHPV testing detects over $90 \%$ of all high-grade cervical intraepithelial neoplasia (CIN) and is therefore an attractive screening tool, especially in countries with established screening infrastructure. Several countries are due to implement primary hrHPV testing with triage by cytology or, in some settings, partial genotyping ${ }^{15}$. Large randomised controlled trials have shown that hrHPV testing, when implemented over several rounds of screening, provided greater protection against $\mathrm{CIN} 2+$ or invasive cervical cancer than did cytological screening. Of note, protection was greater with hrHPV screening in women at $30+$ years of age and with a screening interval of 5 years than cytological screening every 3 years ${ }^{16-19}$. Even a single round of HPV testing can have a significant impact on the rate of advanced cervical cancers and cancer deaths in rural India ${ }^{20}$. Currently, the implementation of molecular testing in LMICs is limited because of cost and infrastructure requirements ${ }^{15}$. However, this might be addressed by using rapid low-cost point-of-care tests such as Xpert HPV, which has shown promise in a field trial in Papua New Guinea ${ }^{21}$.
HPV self-testing to collect cervical/vaginal cells offers the potential to improve screening coverage: meta-analyses have concluded that self-testing increased the participation of non-attenders in screening programmes when sampling kits were provided directly to all participants ${ }^{22}$. However, the effectiveness of screening by self-sampling is determined in part by the performance of the HPV PCR test when applied to self-samples ${ }^{23}$. To bridge the prevention gap in low-/middle- income settings, approaches such as hrHPV self-testing are viable and enable invitation of communities who test positive to attend further triaging ${ }^{24,25}$. Visual inspection of the cervix with acetic acid (VIA) or Lugol's iodine (VILI) is a particularly simple and low-cost screening tool that enables trained healthcare workers to detect abnormalities with a speculum examination. Both methods are especially attractive tools for establishing screening in LMICs, where the infrastructure to provide screening at a national level is not yet in place despite increasing awareness of its importance ${ }^{26-28}$. HPV urine testing is a non-invasive alternative to conventional cytology sampling that could improve screening uptake in individuals for whom cervical or vaginal sampling may be difficult. A large meta-analysis confirmed that detection HPV test results in urine generally correlate with HPV testing in clinician-taken samples ${ }^{29,30}$. However, data to support urinary HPV testing for the detection of CIN are currently lacking.

HrHPV genotypes are maintained in the general population owing to productive infections rather than inadvertent cancers. Low-grade lesions (CIN1), where infectious particles are produced and shed, tend to regress spontaneously within 18-36 months in immunocompetent hosts ${ }^{31}$. Whether a productive life cycle is completed or not depends on the infected epithelial site and the hormonal environment $^{32}$. Nevertheless, hrHPV can persist-often for many years-and can drive cell cycle entry and cell proliferation in the basal and parabasal cell layers ${ }^{33}$, which distinguishes them from low-risk HPVs. Progression to cancer is a consequence of persistent hrHPV infection that, following integration of the viral genome into host DNA, drives dysregulated viral gene expression. The hrHPV early proteins E6 and E7 inactivate the host tumour suppressors p53 and retinoblastoma protein, resulting in neoplastic transformation. The distinct susceptibility of the transformation zone to neoplastic transformation and progression may also be linked to the increased accessibility and proliferation of the basal cell layers at this metaplastic epithelium ${ }^{33}$.

Recently, the predictive value of HPV viral load as a measure of persistence has been investigated: several studies have shown that high baseline HPV-16 and -18 viral load or viral load increase over time are associated with persistent infections ${ }^{34-36}$ and low viral load, or a $>100$-fold decline over time, is associated with clearance $^{37-39}$. Higher viral load was also associated with decreased HPV clearance rates in uncircumcised males and homosexual men who smoke ${ }^{40,41}$. Methylation of CpG sites in HPV DNA is a marker of persistent infection, particularly for HPV-16, that may have utility in triage: in a large randomised controlled trial, methylation triage on cervicovaginal self samples was non-inferior to cytology triage on clinician-taken samples for the detection of high-grade $\mathrm{CIN}^{42}$. 


\section{Advances in therapy of HPV-associated disease}

Precancerous cervical lesions can be treated by loop excision of the transformation zone or ablative techniques such as cryotherapy or laser therapy. The use of novel, cheap ablation techniques that do not require external gas supply (such as CryoPen) could provide affordable treatment of precancerous lesions and prevent progression to cancer in $\mathrm{LMICs}^{43}$. Recently, more conservative approaches in the management of moderate (CIN2) lesions have been adopted in the light of large population-based data indicating high regression rates in young, non-smoking, immunocompetent women in whom minimising the risk of future adverse pregnancy outcomes (second-trimester miscarriage and spontaneous pre-term delivery) is a priority ${ }^{44-47}$.

A non-surgical therapy for pre-invasive hrHPV lesions is highly desirable given the disadvantages outlined above and the infrastructure required to deliver and monitor the efficacy of ablative treatment, which is a major challenge for LMICs. In addition, there is a need for better therapeutic options for hrHPV-driven lesions at anogenital sites other than the cervix. Tackling chronic and recurrent HPV-induced lesions and the possibility to scale up patientapplied use in LMICs have led to the development of the topical immune response modulators such as imiquimod and Yallaferon ${ }^{\circledR}$, a recombinant interferon alpha- $2 \mathrm{~b}$ gel, but recurrence rates remain high. Lopinavir and cidofovir, both antiviral drugs, are currently being trialled in precancerous lesions as well as HPV-associated cancers of varying sites ${ }^{48,49}$. Multiple small molecule inhibitors targeting hrHPV DNA-binding activities or the apoptotic sequences of E6/E7 or exhibiting synthetic lethal interactions are still in preclinical development ${ }^{50}$. Adoptive $\mathrm{T}$ cell therapy comprising infusion of E6- and E7-specific tumour-infiltrating T lymphocytes to facilitate tumour shrinkage is a novel approach to the treatment of metastatic cervical cancer that has shown promise in an exploratory clinical study $^{51}$. However, such individualised therapies are challenging to deliver at scale.

Several aspects of hrHPV biology and pathogenesis make it an attractive candidate for targeting with a therapeutic vaccine. The development of a high-grade cervical lesion is the result of failure of host $\mathrm{T}$ cell responses to control or indeed clear hrHPV infection, an uncommon event that typically takes $10-15$ years and is reversible in up to $30 \%$ of cases $^{31,52-54}$. Regression of CIN is associated with infiltration of the lesion by $\mathrm{CD} 8+\mathrm{T}$ cells $\mathrm{s}^{55}$. CD4+ $\mathrm{T}$ cells play a crucial role in orchestrating this effector response: immunosuppressive states (e.g. HIV infection, iatrogenic) are associated with reduced HPV clearance rates and increased risk of progression to invasive cancer ${ }^{56-59}$. T cells recognise viral antigens in the form of peptides that are generated from proteolytically cleaved internal and external proteins and presented on the cell surface in association with HLA class I (CD8+ $\mathrm{T}$ cells) and class II (CD4+ $\mathrm{T}$ cells) molecules. It is hypothesised that boosting naturally induced hrHPV-specific $\mathrm{T}$ cell responses to early viral antigens by vaccination should accelerate the regression of CIN and clearance of infection. Licensed prophylactic vaccines prevent the acquisition of infection through the induction of antibodies to late (capsid) proteins presented in the form of virus-like particles. They have no impact on disease once infection has occurred; therefore, a different vaccine strategy is required to achieve a therapeutic effect. HPV (along with other oncogenic viruses) presents nonself antigens; the development of $\mathrm{T}$ cell tolerance is therefore far less likely than is the case for cancers expressing self-antigens. The oncoproteins E6 and E7 have been the antigens of choice for most therapeutic vaccine candidates to date, as they are expressed throughout the virus life cycle and on transformed cells. The development of therapeutic vaccines for hrHPV has encompassed proteins and peptides, viral, bacterial, and DNA vectors, RNA replicons, and dendritic cell-based approaches. As there have been several recent comprehensive reviews ${ }^{60,61}$, we focus on the most clinically advanced strategies.

Peptide- and protein-based vaccines offer safety, stability, and ease of manufacture. However, they are poorly immunogenic unless administered with adjuvants, which may cause unwanted reactogenicity, and efforts to apply this approach to immunotherapy of hrHPV have generally been unsuccessful. A mix of adjuvanted synthetic long peptides from HPV-16 E6 and E7 was found to induce complete regression in 9 out of 19 women with high-grade vulval intraepithelial neoplasia ${ }^{62}$. This was an important finding given the very low rate of spontaneous regression of vulval intraepithelial neoplasia and high recurrence rate. A randomised placebo-controlled phase II trial was subsequently initiated to assess the same vaccine strategy in women with HPV-16-positive high-grade CIN. Unfortunately, the study was terminated prematurely because of the reluctance of enrolled patients to defer excisional treatment; therefore, the results were inconclusive ${ }^{63}$. A recombinant protein vaccine, GTL001, comprising HPV-16 and -18 E7 fused to catalytically inactive Bordetella pertussis adenylate cyclase, was tested alone and with imiquimod in a phase I study of women with HPV-16 or HPV-18 and normal cytology ${ }^{64}$. Sustained viral clearance was observed in the majority of women receiving the higher vaccine dose together with imiquimod.

DNA vaccines are safe and easy to manufacture, do not require a cold chain, and can be administered repeatedly, as they do not elicit vector-specific immunity. However, despite eliciting potent immune responses in small animal models, immunogenicity in humans has been disappointing. Electroporator delivery and adjuvants can overcome this, albeit at the cost of increasing complexity and reactogenicity. The leading candidate is the VGX-3100 vaccine (Inovio Pharmaceuticals), which comprises synthetic consensus HPV-16 and HPV-18 E6 and E7 genes. It has shown the most encouraging results of any therapeutic HPV vaccine candidate to date in a randomised controlled phase IIb trial in 154 women with $\mathrm{CIN} 2 / 3^{65}$. In the modified intention-to-treat analysis, histopathological regression to CIN1 or normal was significantly more frequent in VGX-3100 recipients than in placebos $(48.2 \%$ vs. 30\%). In a post-hoc analysis, the magnitude of E6-specific $\mathrm{T}$ cell responses was associated with regression of CIN and viral clearance $^{65}$. A similar DNA vaccine expressing E6/E7, GX-188E, was tested in a small uncontrolled study: complete regression and virus clearance was observed in seven out of nine women with CIN3, in association with polyfunctional CD8+ T cell responses ${ }^{66}$.

Viral vector vaccines elicit potent cell-mediated immune responses owing to their capacity for high levels of transgene expression and 
natural adjuvant properties. Heterologous prime-boost viral vector regimens targeting diverse human pathogens have been shown to induce high frequencies of $\mathrm{T}$ cells in clinical trials while avoiding vector-specific immunity ${ }^{67}$. The first trial of a replication-competent vaccinia virus vectored HPV vaccine, TA-HPV, was conducted 20 years ago ${ }^{68}$. A modified vaccinia Ankara (MVA) vectored vaccine encoding E2, a transcriptional regulator of E6 and E7, has been tested in a phase III trial that included 1,176 female subjects with HPV-driven oncogenic and non-oncogenic intraepithelial lesions and 180 males with condylomata only ${ }^{69}$. The vaccine was delivered directly into the affected anogenital tissues. The investigators reported elimination rates of $89 \%$ in females and $100 \%$ in males. When considering only the participants with high-grade lesions (300/1,176 women), the cure rate was $73 \%{ }^{69}$. Although this is higher than the expected spontaneous regression rate, the results should be interpreted with caution, as a control group was lacking.

\section{Role of the cervico-vaginal microbiome in the development of cervical cancer}

HrHPV infections are highly prevalent in sexually active women, yet only a small minority persist and progress to cancer. Reported risk factors for carcinogenesis include smoking, other sexually transmitted pathogens, oral contraceptive use, and socio-economic status. However, few studies have established which of these associations have a mechanistic basis and which are confounders reflecting high-risk sexual behaviour. Recent studies using nextgeneration sequencing to characterise the microbial communities inhabiting the vagina and cervix (the cervico-vaginal microbiome) have suggested a possible role of altered vaginal microbiota in the development of CIN and cervical cancer. The cervico-vaginal microbiome is typically of low diversity and dominated by Lactobacillus species, which are assumed to protect against pathogens by maintaining a low $\mathrm{pH}^{70,71}$. Vaginal dysbiosis (bacterial vaginosis [BV]), a state characterised by paucity or absence of lactobacilli, overgrowth of anaerobes, and high $\mathrm{pH}$, has been implicated in the acquisition and outcome of HPV infections. A systematic review and meta-analysis of 19 studies confirmed an association between $\mathrm{BV}$ and $\mathrm{CIN}^{72}$. However, causality remains uncertain, since the majority of studies were cross-sectional. A reduction in Lactobacilli, increasing vaginal microbial diversity, and dominance of Sneathia species were observed in association with progression of cervical histology from normal through to high-grade CIN $^{73,74}$. In a longitudinal study in which women were sampled twice weekly for 16 weeks, community state types (CSTs, distinct clusters of vaginal bacterial species) were observed to influence both the incidence and the clearance rates of prevalent HPV infection ${ }^{75}$. A low lactobacillus CST was associated with a nearly two-fold higher rate ratio of incident HPV, and HPV clearance was fastest in women with Lactobacillus gasseri-dominated CSTs.

To date, the microbial composition in the vagina and cervix of healthy women has been studied largely through parallel sequencing of the highly conserved 16 s ribosomal RNA subunit genes, which indicates the abundance and diversity of bacteria but does not provide information on the functional activity of the human vaginal microbiota or the diversity of other microbes present. Direct DNA sequencing (metagenomics) has revealed not only a very high prevalence of HPV in healthy women but also a far greater diversity of HPV types than can be detected by conventional typing $^{76}$. Metatranscriptomics approaches can yield more precise information regarding function and thus identify potential targets, such as the metabolically active bacteria in dysbiotic states ${ }^{77}$. A possible interaction between cervical microbiota diversity, histopathological diagnosis of cervical HPV lesion, and cervical cytokine expression was explored in a recent cross-sectional study of women across a spectrum of HPV disease. Expression of IL-4, IL-10, and TGF- $\beta$ was increased in women with cervical cancer compared with those with low-grade $\mathrm{CIN}^{74}$. It was hypothesised that hrHPV E2, E6, and E7 drive the production of immunosuppressive cytokines, which, in turn, increase cervical microbial diversity and proliferation of Sneathia and Fusobacterium species. Collectively, these studies highlight the need for more longitudinal data and for a combined metagenomics/metatranscriptomics approach in order to better understand the complex interplay between the cervico-vaginal microbiota, sexually transmitted pathogens, and host immune system in determining the outcome of hrHPV infections.

\section{Looking forward and challenges to implementation}

Implementation of effective cervical screening is a major medical advance of the late twentieth century, and it will remain an essential tool for cancer prevention for several decades while prophylactic HPV vaccination programmes take effect. The transition from cytology to hrHPV detection as a screening tool has the potential to improve the effectiveness of screening at longer intervals and to increase coverage by enabling self-testing in the community or even at home. Stratification according to age and HR genotype, with fast-tracking of HPV-16-positive cases to colposcopy and treatment could reduce unnecessary referrals and healthcare costs in high-income countries and also facilitate the allocation of limited resources in LMICs. The opportunities available to LMICs through technological innovations in screening and preventive treatment will be missed unless innovative approaches to implementation are adopted. These include "screen and treat" protocols that embed screening by VIA or HPV tests in existing primary healthcare systems, scaling up training of healthcare workers to enable provision of treatment in a greater range of settings than specialised cancer services, and use of smartphone technology for tracking, recalls, and staff training ${ }^{78-80}$. The use of a low-cost ultra-portable tampon-based digital colposcope has been proposed as a novel approach to increase access to screening at the community level and also as a tool for virtual training ${ }^{81}$. Collectively, these efforts could have significant health and socio-economic benefits.

Although the development of specific antiviral agents is slow, alternatives to surgical excision or ablation of CIN such as therapeutic DNA vaccines are on the horizon. With the application of potent viral vector vaccine technologies, we anticipate improvements in the clinical efficacy of these approaches. As our understanding of the microbial and mucosal immune states that lead to persistent hrHPV infection grows, we may identify new agents that can be used to manipulate the local microenvironment for therapeutic benefit.

Competing interests

The authors declare that they have no competing interests.

Grant information

Lucy Dorrell has received financial support from Oxford NIHR Biomedical Research Centre. 
1. Schache AG, Powell NG, Cuschieri KS, et al:: HPV-Related Oropharynx Cancer in the United Kingdom: An Evolution in the Understanding of Disease Etiology. Cancer Res. 2016; 76(22): 6598-6606.

PubMed Abstract | Publisher Full Text

2. Hellner $\mathrm{K}$, Munger $\mathrm{K}$ : Human papillomaviruses as therapeutic targets in human cancer. J Clin Oncol. 2011; 29(13): 1785-94.

PubMed Abstract | Publisher Full Text | Free Full Text

3. Arbyn M, de Sanjose S, Saraiya M, et al:: EUROGIN 2011 roadmap on prevention and treatment of HPV-related disease. Int J Cancer. 2012; 131(9): 1969-82. PubMed Abstract | Publisher Full Text | Free Full Text

4. Plummer M, de Martel C, Vignat J, et al.: Global burden of cancers attributable to infections in 2012: a synthetic analysis. Lancet Glob Health. 2016; 4(9): e609-16. PubMed Abstract | Publisher Full Text

5. $\quad F$ Bruni L, Diaz M, Barrionuevo-Rosas L, et al.: Global estimates of human papillomavirus vaccination coverage by region and income level: a pooled analysis. Lancet Glob Health. 2016; 4(7): e453-63.

PubMed Abstract | Publisher Full Text | F1000 Recommendation

6. Williamson AL: The Interaction between Human Immunodeficiency Virus and Human Papillomaviruses in Heterosexuals in Africa. J Clin Med. 2015; 4(4): 579-92.

PubMed Abstract | Publisher Full Text | Free Full Text

7. Tiggelaar SM, Lin MJ, Viscidi RP, et al:: Age-specific human papillomavirus antibody and deoxyribonucleic acid prevalence: a global review. J Adolesc Health. 2012; 50(2): 110-31.

PubMed Abstract | Publisher Full Text | Free Full Text

8. F Mesher D, Panwar K, Thomas SL, et al:: Continuing reductions in HPV 16/18 in a population with high coverage of bivalent HPV vaccination in England: an ongoing cross-sectional study. BMJ Open. 2016; 6(2): e009915.

PubMed Abstract | Publisher Full Text | Free Full Text | F1000 Recommendation

9. af Geijersstam V, Eklund C, Wang Z, et al:: A survey of seroprevalence of human papillomavirus types 16, 18 and $\mathbf{3 3}$ among children. Int J Cancer. 1999; 80(4): 489-93.

PubMed Abstract | Publisher Full Text

10. Syrjanen S: Current concepts on human papillomavirus infections in children. APMIS. 2010; 118(6-7): 494-509.

PubMed Abstract | Publisher Full Text

11. Alemany L, Cubilla A, Halec G, et al.: Role of Human Papillomavirus in Penile Carcinomas Worldwide. Eur Urol. 2016; 69(5): 953-61.

PubMed Abstract | Publisher Full Text

12. Arbyn $\mathrm{M}$, Bergeron $\mathrm{C}$, Klinkhamer $\mathrm{P}$, et al.: Liquid compared with conventional cervical cytology: a systematic review and meta-analysis. Obstet Gynecol. 2008; 111(1): 167-77.

PubMed Abstract | Publisher Full Text

13. F Vaccarella S, Franceschi S, Zaridze D, et al.: Preventable fractions of cervical cancer via effective screening in six Baltic, central, and eastern European countries 2017-40: a population-based study. Lancet Oncol. 2016 17(10): 1445-52.

PubMed Abstract | Publisher Full Text | Free Full Text | F1000 Recommendation

14. Bloom D, Cafiero E, Jané-Llopis E, et al.: The Global Economic Burden of Noncommunicable Diseases. Geneva; 2011.

Reference Source

15. Wentzensen N, Arbyn M, Berkhof J, et al.: Eurogin 2016 Roadmap: How HPV knowledge is changing screening practice. Int J Cancer. 2016. PubMed Abstract | Publisher Full Text

16. Arbyn M, Ronco G, Anttila A, et al.: Evidence regarding human papillomavirus testing in secondary prevention of cervical cancer. Vaccine. 2012; 30 Suppl 5 : F88-99.

PubMed Abstract | Publisher Full Text

17. Rijkaart DC, Berkhof $\mathrm{J}$, van Kemenade FJ, et al:: HPV DNA testing in populationbased cervical screening (VUSA-Screen study): results and implications. $\mathrm{Br} J$ Cancer. 2012; 106(5): 975-81.

PubMed Abstract | Publisher Full Text | Free Full Text

18. F Ronco G, Dillner J, Elfström KM, et al.: Efficacy of HPV-based screening for prevention of invasive cervical cancer: follow-up of four European randomised controlled trials. Lancet. 2014; 383(9916): 524-32.

PubMed Abstract | Publisher Full Text | F1000 Recommendation

19. F C Kitchener H, Canfell K, Gilham C, et al:: The clinical effectiveness and cost-effectiveness of primary human papillomavirus cervical screening in England: extended follow-up of the ARTISTIC randomised trial cohort through three screening rounds. Health Technol Assess. 2014; 18(23): 1-196. PubMed Abstract | Publisher Full Text | Free Full Text | F1000 Recommendation

20. F Sankaranarayanan R, Nene BM, Shastri SS, et al.: HPV screening for cervical cancer in rural India. N Engl J Med. 2009; 360(14): 1385-94. PubMed Abstract | Publisher Full Text | F1000 Recommendation

21. F Toliman P, Badman SG, Gabuzzi J, et al.: Field Evaluation of Xpert HPV Point-of-Care Test for Detection of Human Papillomavirus Infection by Use of Self-Collected Vaginal and Clinician-Collected Cervical Specimens. J Clin Microbiol. 2016: 54(7): 1734-7.

PubMed Abstract | Publisher Full Text | Free Full Text | F1000 Recommendation
22. $F$ Verdoodt $F$, Jentschke $M$, Hillemanns $P$, et al: Reaching women who do not participate in the regular cervical cancer screening programme by offering self-sampling kits: a systematic review and meta-analysis of randomised trials. Eur J Cancer. 2015; 51(16): 2375-85.

PubMed Abstract | Publisher Full Text | F1000 Recommendation

23. Arbyn M, Verdoodt F, Snijders PJ, et al:: Accuracy of human papillomavirus testing on self-collected versus clinician-collected samples: a meta-analysis. Lancet Oncol. 2014; 15(2): 172-83.

PubMed Abstract | Publisher Full Text

24. Arrossi S, Thouyaret L, Herrero R, et al:: Effect of self-collection of HPV DNA offered by community health workers at home visits on uptake of screening for cervical cancer (the EMA study): a population-based cluster-randomised trial. Lancet Glob Health. 2015; 3(2): e85-94.

PubMed Abstract | Publisher Full Text

25. Untiet $\mathrm{S}$, Vassilakos $\mathrm{P}, \mathrm{McC}$ arey $\mathrm{C}$, et al.: HPV self-sampling as primary screening test in sub-Saharan Africa: implication for a triaging strategy. Int $J$ Cancer. 2014; 135(8): 1911-7.

PubMed Abstract | Publisher Full Text

26. F Fokom-Domgue J, Combescure C, Fokom-Defo V, et al.: Performance of alternative strategies for primary cervical cancer screening in sub-Saharan Africa: systematic review and meta-analysis of diagnostic test accuracy studies. BMJ. 2015; 351: h3084.

PubMed Abstract | Publisher Full Text | Free Full Text | F1000 Recommendation

27. Shi JF, Canfell K, Lew JB, et al:: Evaluation of primary HPV-DNA testing in relation to visual inspection methods for cervical cancer screening in rural China: an epidemiologic and cost-effectiveness modelling study. BMC Cancer. 2011; 11: 239

PubMed Abstract | Publisher Full Text | Free Full Text

28. F Shastri SS, Mittra I, Mishra GA, et al.: Effect of VIA screening by primary health workers: randomized controlled study in Mumbai, India. J Nat/ Cancer Inst. 2014; 106(3): dju009.

PubMed Abstract | Publisher Full Text | Free Full Text | F1000 Recommendation

29. F Pathak N, Dodds J, Zamora J, et al: Accuracy of urinary human papillomavirus testing for presence of cervical HPV: systematic review and meta-analysis. BMJ. 2014; 349: g5264.

PubMed Abstract | Publisher Full Text | Free Full Text | F1000 Recommendation

30. Piyathilake $\mathrm{CJ}$, Badiga S, Chambers MM, et al.: Accuracy of urinary human papillomavirus testing for the presence of cervical human papillomaviruses and higher grades of cervical intraepithelial neoplasia. Cancer. 2016; 122(18): 2836-44.

PubMed Abstract | Publisher Full Text | Free Full Text

31. Moscicki AB, Shiboski S, Hills NK, et al:: Regression of low-grade squamous intra-epithelial lesions in young women. Lancet. 2004; 364(9446): 1678-83. PubMed Abstract | Publisher Full Text

32. Gariglio $\mathrm{P}$, Gutiérrez J, Cortés $\mathrm{E}$, et al:: The role of retinoid deficiency and estrogens as cofactors in cervical cancer. Arch Med Res. 2009; 40(6): 449-65. PubMed Abstract | Publisher Full Text

33. Doorbar J, Quint W, Banks L, et al:: The biology and life-cycle of human papillomaviruses. Vaccine, 2012; 30 Suppl 5: F55-70. PubMed Abstract | Publisher Full Text

34. F Winer RL, Xi LF, Shen Z, et al.: Viral load and short-term natural history of type-specific oncogenic human papillomavirus infections in a high-risk cohort of midadult women. Int J Cancer. 2014; 134(8): 1889-98. PubMed Abstract | Publisher Full Text | Free Full Text | F1000 Recommendation

35. F Fu TC, Fu Xi L, Hulbert A, et al.: Short-term natural history of high-risk human papillomavirus infection in mid-adult women sampled monthly. Int J Cancer. 2015; 137(10): 2432-42.

PubMed Abstract | Publisher Full Text | Free Full Text | F1000 Recommendation

36. $\mathrm{F}$ van der Weele $\mathrm{P}$, van Logchem $\mathrm{E}$, Wolffs $\mathrm{P}$, et al.: Correlation between viral load, multiplicity of infection, and persistence of HPV16 and HPV18 infection in a Dutch cohort of young women. J Clin Virol. 2016; 83: 6-11. PubMed Abstract | Publisher Full Text | F1000 Recommendation

37. Carcopino X, Henry M, Mancini J, et al.: Two years outcome of women infected with high risk HPV having normal colposcopy following low-grade or equivocal cytological abnormalities: are HPV16 and 18 viral load clinically useful predictive markers? J Med Virol. 2012; 84(6): 964-72.

PubMed Abstract | Publisher Full Text

38. Trevisan A, Schlecht NF, Ramanakumar AV, et al.: Human papillomavirus type 16 viral load measurement as a predictor of infection clearance. J Gen Virol. 2013; 94(Pt 8): 1850-7

PubMed Abstract | Publisher Full Text | Free Full Text

39. Marks M, Gravitt PE, Utaipat U, et al:: Kinetics of DNA load predict HPV 16 viral clearance. J Clin Virol. 2011; 51(1): 44-9.

PubMed Abstract | Publisher Full Text | Free Full Text

40. F Senkomago V, Backes DM, Hudgens MG, et al:: Higher HPV16 and HPV18 Penile Viral Loads Are Associated With Decreased Human Papillomavirus Clearance in Uncircumcised Kenyan Men. Sex Transm Dis. 2016; 43(9): 572-8. PubMed Abstract | Publisher Full Text | Free Full Text | F1000 Recommendation 
41. F Wieland $\mathrm{U}$, Hellmich $\mathrm{M}$, Wetendorf $\mathrm{J}$, et al:: Smoking and anal high-risk human papillomavirus DNA loads in HIV-positive men who have sex with men. Int J Med Microbiol. 2015; 305(7): 689-96. PubMed Abstract | Publisher Full Text | F1000 Recommendation

42. F Verhoef VM, Bosgraaf RP, van Kemenade FJ, et al.: Triage by methylationmarker testing versus cytology in women who test HPV-positive on selfcollected cervicovaginal specimens (PROHTECT-3): a randomised controlled non-inferiority trial. Lancet Oncol. 2014; 15(3): 315-22.

PubMed Abstract | Publisher Full Text | F1000 Recommendation

43. Tsu V, Jerónimo J: Saving the World's Women from Cervical Cancer. N Engl J Med. 2016; 374(26): 2509-11.

PubMed Abstract | Publisher Full Text

44. Khalid S, Dimitriou E, Conroy R, et al.: The thickness and volume of LLETZ specimens can predict the relative risk of pregnancy-related morbidity. BJOG. 2012; 119(6): 685-91

PubMed Abstract | Publisher Full Text

45. Poon LC, Savvas M, Zamblera D, et al.: Large loop excision of transformation zone and cervical length in the prediction of spontaneous preterm delivery. BJOG. 2012; 119(6): 692-8. PubMed Abstract | Publisher Full Text

46. F Kyrgiou M, Mitra A, Arbyn M, et al.: Fertility and early pregnancy outcomes after treatment for cervical intraepithelial neoplasia: systematic review and meta-analysis. BMJ. 2014; 349: g6192.

PubMed Abstract | Publisher Full Text | Free Full Text | F1000 Recommendation

47. Kyrgiou M, Athanasiou A, Paraskevaidi M, et al:: Adverse obstetric outcomes after local treatment for cervical preinvasive and early invasive disease according to cone depth: systematic review and meta-analysis. BMJ. 2016; 354: i3633. PubMed Abstract | Publisher Full Text | Free Full Text

48. Hampson L, Maranga IO, Masinde MS, et al:: A Single-Arm, Proof-Of-Concept Trial of Lopimune (Lopinavir/Ritonavir) as a Treatment for HPV-Related PreInvasive Cervical Disease. PLoS One. 2016; 11(1): e0147917. PubMed Abstract | Publisher Full Text | Free Full Text

49. F Stier EA, Goldstone SE, Einstein MH, et al:: Safety and efficacy of topical cidofovir to treat high-grade perianal and vulvar intraepithelial neoplasia in HIV-positive men and women. AIDS. 2013; 27(4): 545-51. PubMed Abstract | Publisher Full Text | Free Full Text | F1000 Recommendation

50. Stern PL, van der Burg SH, Hampson IN, et al.: Therapy of human papillomavirus-related disease. Vaccine. 2012; 30(Suppl 5): F71-82. PubMed Abstract | Publisher Full Text | Free Full Text

51. F Stevanović S, Draper LM, Langhan MM, et al:: Complete regression of metastatic cervical cancer after treatment with human papillomavirus-targeted tumor-infiltrating T cells. J Clin Oncol. 2015; 33(14): 1543-50.

PubMed Abstract | Publisher Full Text | Free Full Text | F1000 Recommendation

52. Trimble $\mathrm{CL}$, Piantadosi $\mathrm{S}$, Gravitt $\mathrm{P}$, et al:: Spontaneous regression of high-grade cervical dysplasia: effects of human papillomavirus type and HLA phenotype. Clin Cancer Res. 2005; 11(13): 4717-23.

PubMed Abstract | Publisher Full Text | Free Full Text

53. Farhat S, Nakagawa M, Moscicki AB: Cell-mediated immune responses to human papillomavirus $16 \mathrm{E} 6$ and $\mathrm{E} 7$ antigens as measured by interferon gamma enzyme-linked immunospot in women with cleared or persistent human papillomavirus infection. Int J Gynecol Cancer. 2009; 19(4): 508-12. PubMed Abstract | Publisher Full Text | Free Full Text

54. Woo YL, van den Hende M, Sterling JC, et al.: A prospective study on the natural course of low-grade squamous intraepithelial lesions and the presence of HPV16 E2-, E6- and E7-specific T-cell responses. Int J Cancer. 2010; 126(1): $133-41$

PubMed Abstract | Publisher Full Text

55. F Trimble CL, Clark RA, Thoburn C, et al.: Human papillomavirus 16associated cervical intraepithelial neoplasia in humans excludes CD8 T cells from dysplastic epithelium. $J$ Immunol. 2010; 185(11): 7107-14. PubMed Abstract | Publisher Full Text | Free Full Text | F1000 Recommendation

56. Steele JC, Mann $\mathrm{CH}$, Rookes S, et al:: T-cell responses to human papillomavirus type 16 among women with different grades of cervical neoplasia. $\mathrm{Br} J$ Cancer. 2005; 93(2): 248-59.

PubMed Abstract | Publisher Full Text | Free Full Text

57. Dillon S, Sasagawa T, Crawford A, et al:: Resolution of cervical dysplasia is associated with T-cell proliferative responses to human papillomavirus type 16 E2. J Gen Virol. 2007; 88(Pt 3): 803-13.

PubMed Abstract | Publisher Full Tex

58. Kim KH, Greenfield WW, Cannon MJ, et al.: CD4+ T-cell response against human papillomavirus type $16 \mathrm{E} 6$ protein is associated with a favorable clinical trend. Cancer Immunol Immunother. 2012; 61(1): 63-70. PubMed Abstract | Publisher Full Text | Free Full Text

59. Reusser NM, Downing C, Guidry J, et al:: HPV Carcinomas in Immunocompromised Patients. J Clin Med. 2015; 4(2): 260-81. PubMed Abstract | Publisher Full Text | Free Full Text

60. Vici P, Pizzuti L, Mariani L, et al.: Targeting immune response with therapeutic vaccines in premalignant lesions and cervical cancer: hope or reality from clinical studies. Expert Rev Vaccines. 2016; 15(10): 1327-36. PubMed Abstract | Publisher Full Text | Free Full Text

61. Yang A, Jeang J, Cheng K, et al.: Current state in the development of candidate therapeutic HPV vaccines. Expert Rev Vaccines. 2016; 15(8): 989-1007. PubMed Abstract | Publisher Full Text | Free Full Text
62. F Kenter GG, Welters MJ, Valentijn AR, et al:: Vaccination against HPV-16 oncoproteins for vulvar intraepithelial neoplasia. N Engl J Med. 2009; 361(19): $1838-47$

PubMed Abstract | Publisher Full Text | F1000 Recommendation

63. de Vos van Steenwijk PJ, Ramwadhdoebe TH, Löwik MJ, et al.: A placebocontrolled randomized HPV16 synthetic long-peptide vaccination study in women with high-grade cervical squamous intraepithelial lesions. Cancer Immunol Immunother. 2012; 61(9): 1485-92. PubMed Abstract | Publisher Full Text | Free Full Text

64. F van Damme P, Bouillette-Marussig M, Hens A, et al.: GTL001, A Therapeutic Vaccine for Women Infected with Human Papillomavirus 16 or 18 and Norma Cervical Cytology: Results of a Phase I Clinical Trial. Clin Cancer Res. 2016 22(13): 3238-48.

PubMed Abstract | Publisher Full Text | F1000 Recommendation

65. F Trimble CL, Morrow MP, Kraynyak KA, et al: Safety, efficacy, and immunogenicity of VGX-3100, a therapeutic synthetic DNA vaccine targeting human papillomavirus 16 and $18 \mathrm{E} 6$ and E7 proteins for cervical intraepithelial neoplasia 2/3: a randomised, double-blind, placebo-controlled phase $2 \mathrm{~b}$ trial. Lancet. 2015; 386(10008): 2078-88.

PubMed Abstract | Publisher Full Text | Free Full Text | F1000 Recommendation

66. Kim TJ, Jin HT, Hur SY, et al:: Clearance of persistent HPV infection and cervical lesion by therapeutic DNA vaccine in CIN3 patients. Nat Commun. 2014 ; 53 : 5317.

PubMed Abstract | Publisher Full Text | Free Full Text

67. Ewer KJ, Lambe T, Rollier CS, et al:: Viral vectors as vaccine platforms: from mmunogenicity to impact. Curr Opin Immunol. 2016; 41: 47-54. PubMed Abstract | Publisher Full Text

68. Borysiewicz LK, Fiander A, Nimako $M$, et al.: A recombinant vaccinia virus encoding human papillomavirus types 16 and 18, E6 and E7 proteins as immunotherapy for cervical cancer. Lancet. 1996; 347(9014): 1523-7. PubMed Abstract | Publisher Full Text

69. F Rosales R, López-Contreras M, Rosales C, et al:: Regression of human papillomavirus intraepithelial lesions is induced by MVA E2 therapeutic vaccine. Hum Gene Ther. 2014; 25(12): 1035-49. PubMed Abstract | Publisher Full Text | Free Full Text | F1000 Recommendation

70. $\mathrm{F}$ Ravel J, Gajer $\mathrm{P}, \mathrm{Abdo} \mathrm{Z}$, et al:: Vaginal microbiome of reproductive-age women. Proc Natl Acad Sci U S A. 2011; 108(Suppl 1): 4680-7. PubMed Abstract | Publisher Full Text | Free Full Text | F1000 Recommendation

71. Smith BC, McAndrew T, Chen Z, et al:: The cervical microbiome over 7 years and a comparison of methodologies for its characterization. PLOS One. 2012; 7(7): e40425.

PubMed Abstract | Publisher Full Text | Free Full Text

72. Gillet $\mathrm{E}$, Meys JF, Verstraelen $\mathrm{H}$, et al:: Association between bacterial vaginosis and cervical intraepithelial neoplasia: systematic review and meta-analysis. PLoS One. 2012; 7(10): e45201. PubMed Abstract | Publisher Full Text | Free Full Text

73. F Mitra A, MacIntyre DA, Lee YS, et al:: Cervical intraepithelial neoplasia disease progression is associated with increased vaginal microbiome diversity. Sci Rep. 2015; 5(5): 16865

PubMed Abstract | Publisher Full Text | Free Full Text | F1000 Recommendation

74. F Audirac-Chalifour A, Torres-Poveda K, Bahena-Román M, et al.: Cervical Microbiome and Cytokine Profile at Various Stages of Cervical Cancer: A Pilot Study. PLoS One. 2016; 11(4): e0153274.

PubMed Abstract | Publisher Full Text | Free Full Text | F1000 Recommendation

75. F Brotman RM, Shardell MD, Gajer P, et al:: Interplay between the tempora dynamics of the vaginal microbiota and human papillomavirus detection. J Infect Dis. 2014: 210(11): 1723-33.

PubMed Abstract | Publisher Full Text | Free Full Text | F1000 Recommendation

76. Ma $Y$, Madupu $R$, Karaoz $U$, et al:: Human papillomavirus community in healthy persons, defined by metagenomics analysis of human microbiome project shotgun sequencing data sets. $J$ Virol. 2014; 88(9): 4786-97. PubMed Abstract | Publisher Full Text | Free Full Text

77. Twin J, Bradshaw CS, Garland SM, et al:: The potential of metatranscriptomics for identifying screening targets for bacterial vaginosis. PLoS One. 2013; 8(9): e76892.

PubMed Abstract | Publisher Full Text | Free Full Text

78. F Pimple S, Mishra G, Shastri S: Global strategies for cervical cancer prevention. Curr Opin Obstet Gynecol. 2016; 28(1): 4-10. PubMed Abstract | Publisher Full Text | F1000 Recommendation

79. F Campbell C, Kafwafwa S, Brown H, et al.: Use of thermo-coagulation as an alternative treatment modality in a 'screen-and-treat' programme of cervical screening in rural Malawi. Int J Cancer. 2016; 139(4): 908-15. PubMed Abstract | Publisher Full Text | Free Full Text | F1000 Recommendation

80. F Asgary R, Adongo PB, Nwameme A, et al:: mHealth to Train Community Health Nurses in Visual Inspection With Acetic Acid for Cervical Cancer Screening in Ghana. J Low Genit Tract Dis. 2016; 20(3): 239-42. PubMed Abstract | Publisher Full Text | Free Full Text | F1000 Recommendation

81. F Lam CT, Krieger MS, Gallagher JE, et al:: Design of a Novel Low Cost Point of Care Tampon (POCkeT) Colposcope for Use in Resource Limited Settings. PLoS One. 2015; 10(9): e0135869.

PubMed Abstract | Publisher Full Text | Free Full Text | F1000 Recommendation 


\section{Open Peer Review}

\section{Current Peer Review Status:}

\section{Editorial Note on the Review Process}

Faculty Reviews are review articles written by the prestigious Members of Faculty Opinions. The articles are commissioned and peer reviewed before publication to ensure that the final, published version is comprehensive and accessible. The reviewers who approved the final version are listed with their names and affiliations.

\section{The reviewers who approved this article are:}

\section{Version 1}

\section{Sarah Fidler}

St Mary's NHS Trust and Imperial College, London, UK

Competing Interests: No competing interests were disclosed.

\section{Yin Ling Woo}

Department of Obstetrics and Gynaecology, Faculty of Medicine, University of Malaya, Kuala Lumpur, Malaysia

Competing Interests: No competing interests were disclosed.

\section{Marc Arbyn}

Unit of Cancer Epidemiology/Belgian Cancer Centre, Scientific Institute of Public Health, Brussels, Belgium

Competing Interests: No competing interests were disclosed.

The benefits of publishing with F1000Research:

- Your article is published within days, with no editorial bias

- You can publish traditional articles, null/negative results, case reports, data notes and more

- The peer review process is transparent and collaborative

- Your article is indexed in PubMed after passing peer review

- Dedicated customer support at every stage

For pre-submission enquiries, contact research@f1000.com 